\title{
Researching chronic childhood illness: the example of childhood cancer
}

\author{
MARY DIXON-WOODS ${ }^{\star}$, BRIDGET YOUNG ${ }^{\dagger}$ and EMMA ROSS ${ }^{\ddagger}$
}

${ }^{\star}$ Department of Health Sciences, University of Leicester, 22-28 Princess Road West, Leicester LE1 6TP, UK

${ }^{\dagger}$ Division of Clinical Psychology, University of Liverpool, The Whelan Building, Quadrangle, Brownlow Hill, Liverpool L69 3GB, UK

${ }^{\ddagger}$ Paediatric Oncology, Children's Hospital, Leicester Royal Infirmary, Leicester LE1 5WW, UK

Received 12 April 2006, Accepted 23 fune 2006

Objectives: To provide an overview of issues raised by conducting research in the area of chronic childhood illness, using the example of childhood cancer.

Methods: This literature review used informal methods.

Results: Children with cancer and their families may participate in a wide variety of studies in different research traditions, including social science studies, epidemiological, biological and genetic research, and clinical trials. Different concerns about research participation have been raised in these different contexts. Sociological debate has tended to characterize exclusion from research as a manifestation of assumptions of poor competence on the part of children, and to see inclusion in research as a means of restoring proper balance in power relations and giving children a voice. The ethical imperative within clinical research, on the other hand, has been in favour of protection of individuals from risk or direct harm. Lack of consensus on issues such as the status of children's consent for research participation persists, in part because debates have taken place within rather than across disciplinary boundaries, and in part because of a tendency to debate issues as ethical principles in an empirical vacuum. The lack of research on the experiences and views of those asked to take part in childhood cancer research is striking.

Discussion: It is important that debates about the involvement of children in research are informed by high-quality social science research and by interdisciplinary dialogue.

Keywords: Childhood cancer, Ethics, Research participation

\section{INTRODUCTION}

In most areas of paediatrics, the evidence base relies on research conducted on adults. Until recently, children were routinely excluded from clinical research, partly on the grounds that they were regarded as incapable of providing informed consent. ${ }^{1}$ This has recently changed: in the USA, the Food and Drug Administration now requires drug manufacturers to test new drugs on children, and the National Institutes of Health have adopted a policy requiring researchers to

Reprint requests to: Mary Dixon-Woods.

Email: md11@1e.ac.uk; fax: +441162523272 include children as research participants or to explain why they have been excluded. ${ }^{2}$ In the UK, the Royal College of Paediatrics and Child Health ${ }^{3}$ and the Medical Research Council ${ }^{4}$ similarly emphasize the importance of children's involvement in research, while the UK Department of Health has recently invested $£ 20$ million to establish the Medicines for Children Research Network, whose aim is to coordinate clinical studies into the safety and effectiveness of medicines for children. Other major research groups and legislative, commercial and professional bodies worldwide have joined the call for randomized controlled trials to evaluate therapies to be used with children, encouraged by the 
European Clinical Trials Directive (2001/ 20/EC). As well as trials, children with chronic illnesses and their families are involved in a range of other types of study, including biological, epidemiological and genetic research and social science research.

The participation of children in research raises important questions, and codes of practice on the ethics of research in childhood have proliferated. In this paper, we provide, using informal methods of review, an overview of the issues raised by children's participation in research, using the exemplar area of childhood cancer. This is a particularly apt area, because of the unusually high participation of children with cancer in research. ${ }^{5}$ We suggest that social science has engaged in heated debates about its own methods for studying children, but relatively little attention has been given to aspects of participation in other forms of research in childhood cancer. We argue that social science research and theory about people's participation in childhood cancer research is urgently needed, not least to inform rapidly developing normative legal and ethical frameworks nationally and internationally. ${ }^{6}$

\section{ETHICS OF RESEARCH ABOUT CHILDHOOD}

Most discussions of the ethics of different forms of research in childhood occur within, rather than across, disciplinary boundaries. Within social science research, the imperative for increasing the involvement of children in research has often come, particularly within some branches of sociology of childhood, from a concern for the emancipation of children, ${ }^{7}$ and the argument that social science research must allow children to be heard themselves as well as being reported on by others. ${ }^{8}$ Alderson, ${ }^{9}$ for example, proposes that direct involvement of children in research can:

Rescue them from silence and exclusion, and from being represented, by default, as passive objects, while respect for their informed and involuntary consent helps to protect them from covert, invasive, exploitative or abusive research.

In discussing risks of research, sociological debate in particular has focused on issues of power relations and probity and rather less on the potential for direct harm to children's health and wellbeing (although that too has been a concern in some writing). ${ }^{10}$

By contrast, debates within the clinical sciences (including epidemiology, biology, genetics, and trials), broadly speaking, have been concerned with the possible harms to children that might arise from their participation in research. The key dilemma is that there is a desire for children to benefit from the progress in medical care that scientific research can bring, but at the same time a need to avoid placing any individual children at risk of being harmed by such research.${ }^{11} \mathrm{It}$ is clear that strong concern about children's vulnerability underlies the bioethical standpoint on children's participation in scientific research, ${ }^{12}$ including concerns about the potential weakness of protective mechanisms such as informed consent procedures in the case of children. ${ }^{13}$

Recommended practice in relation to clinical research with children clearly reflects the tensions between valuing children's autonomy and protecting them. For example, the Declaration of Helsink $\mathrm{i}^{14}$ proposes that the assent of those deemed legally to be minors be obtained in addition to the consent of a legally authorized representative, providing children ('if able' to assent) with the right to refuse to participate in research. This approach has, however, raised questions about the extent to which a requirement for parents' consent frames children's assent or consent in a hierarchy where legally authorized representatives are given greater powers within the consent process than children themselves. ${ }^{15}$ Interestingly, the Human Tissue Act 2004, for the first time in English law, makes statutory provision for children 'with capacity' to consent to the use of their bodily material for therapeutic or research purposes. 
Guidance on 'good practice' from professional organizations in the social sciences continues to demonstrate ambiguity about the autonomy of children in consenting to research. As Morrow and Richards ${ }^{12}$ note, the British Psychological Society ${ }^{16}$ guidance groups children with 'participants who have impairments that will limit understanding and/or communication', and further proposes that children require special safeguarding procedures. It suggests that 'real consent' should be obtained from children, but consent should additionally be obtained from parents/carers for people aged under 16 years. The British Sociological Association $^{17}$ similarly argues that research with children requires additional care, and proposes that the consent of the child should be sought in addition to that of the parent. The American Sociological Association ${ }^{18}$ also proposes that parental consent should be obtained, although it recognizes that there are specific circumstances (e.g. research involving abused children) where it might not be appropriate to do so.

It is unclear why in many codes of practice the consent of parents/carers is required in addition to that of the child, appearing to imply that the consent of the child is insufficient, and failing to make clear what should happen when one of the parties involved dissents. More generally, these codes of practice reflect considerable caution about children's capacity to consent and assumptions about the inevitability of children's vulnerability. However, research to investigate children's experiences of participating in research, which would explore issues around children's capacities, preferences, and willingness to be involved in design, implementation and interpretation, has been largely lacking, as we shall show below in our discussion of research within different traditions.

\section{SOCIAL SCIENCE RESEARCH}

Social science research spans a number of disciplines, from sociology and anthropology to social policy and psychology. An ongoing, and unresolved, methodological debate within the social sciences focuses on how children should be researched, and whether 'special' techniques are required. Some authors $^{19}$ emphasize the 'specialness' of children and the need for specific research techniques to allow research with children, describing a range of techniques, including drawing, playing (e.g. using dolls and puppets), and story completion.

Within psychology, such issues are mostly uncontroversial: it is widely accepted that maturational and developmental features of childhood usually demand the use of unique or special research instruments and paradigms, particularly for work with very young children and infants. By contrast, some sociologists argue that using 'special' techniques risks reinforcing the notion of children as 'other', and that the assumption that methods should be based on the age of children is flawed. ${ }^{20}$ Some sociological researchers ${ }^{21}$ have made the case that using 'special' methods is unnecessary, and that children can be engaged in research through conventional techniques, such as conversational interviews, already used with adults, although they do recognize a role for playbased activities to prompt discussion. Christensen and James ${ }^{22}$ argue similarly that when choosing methods for working with children, the basic principle is as it would be with any other piece of research (with adults): the methods must suit the people involved in the study, the kinds of research question being investigated, and the specific social and cultural context of the research.

The assumption that children might not be competent to consent to or participate in particular forms of research has come under particular criticism. Mayall, ${ }^{23}$ for example, argues that complications do not arise from children's inherent inabilities or misperceptions, but from the social positions ascribed to children. The major issues of the researcher-researched relationship are thus argued to be essentially the same with children as they are with adults. ${ }^{24}$ 
However, there are contradictions even within this position. Although there are arguments on the one hand that 'special' methods are not needed, the need for a democratization, to provide opportunities for children to resist the researchers' control of the research process, has been emphasized. ${ }^{23}$ This has often taken the form of arguing for the involvement of children themselves in the research process, encouraging them to collect data and assist in its analysis. This model of using age-adjacent researchers would, however, seem to qualify as a 'special' technique, since it is not used with adults. There are few examples as yet of this model in childhood cancer research, but it is likely to require more critical evaluation than it has yet received. For example, the ethical and confidentiality issues that arise in asking children to collect data (or even analyse data) from other ill children would need careful assessment.

There are other problems with approaches that seek to downplay the significance of age as an important consideration in research design. Although James et al. ${ }^{20}$ describe agebased methodologies as seductive rather than sound, it could be argued that they may well be necessary: there are stubborn realities about what children are characteristically like at particular ages (4-year-olds, for example, are characteristically not like 8 -year-olds) that may need to be accounted for in studies. Similarly, the argument that children are competent is repeatedly asserted rather than demonstrated in this literature, but this might not survive a reading of contemporary developmental psychology. ${ }^{4}$

Although qualitative research is by no means the only research approach used in social science research on childhood, it has been seen in some quarters as linked to an emancipatory or participatory agenda, and to be vital in accessing and understanding the views of children and in promoting an understanding of children's agency as well as how their experiences are shaped by their environments. In particular, ethnography, involving observations and informal interviews, has been seized upon by those working within the sociology of childhood as the means by which the authentic voices of children might be accessed. ${ }^{25}$ Ethnographic work with children has a distinguished history in education studies and the sociology of education, where children's behaviours have been studied through classroom observations and other techniques, ${ }^{26,27}$ and the approach has been used with considerable success in the study of experiences of childhood cancer (most notably, perhaps, in Bluebond-Langner's ${ }^{28}$ classic work).

Harden et al. ${ }^{21}$ note some of the difficulties associated with mounting ethnographic studies of children, however. They point, for example, to problems of access, particularly to sites involving family life. Hospitals may be relatively easy places to access; the frequent presence of an observer in the home may be much less acceptable, but home may be where much of the action takes place. Shaw $^{29}$ and Mauthner ${ }^{30}$ discuss the problems of trust that arise in conducting research using qualitative techniques with children. Ethnographic work raises particular problems, because of the potential for children (and parents) to develop trusting relationships with researchers. Such relationships may subsequently cause discomfort when research findings result in participants feeling that they have been betrayed by a friend. Disclosures, or allegations of physical, emotional or sexual harm, may be made that may require researchers to break confidentiality and intervene. Ethnographers may witness unacceptable or risky behaviour, and experience acute dilemmas about whether and when to intervene. Ethnography is clearly a hugely promising methodology for studying experiences of chronic childhood illness, but more exploration and reflexive accounts about conducting ethnography in this area are needed.

Along with ethnography, qualitative interviews with children have a long history. Notwithstanding the argument that children 
do not require 'special' techniques, or that age-based methodologies are not necessary, it is clear that there are important differences between children of different ages in their ability and willingness to provide accounts of their experiences, and a good understanding of the development of narrative competence in children is needed. ${ }^{31}$ For example, in our own experience of conducting research in childhood cancer, children under the age of 8 years typically (though not always) offer only very limited and brief accounts in a semi-structured interview, and often appear to be uncomfortable with this approach. By contrast, older children and young people may particularly like this type of research approach if carefully and skilfully handled much depends not on the research design but on the ability of the interviewer to create rapport and comfort. Children's accounts in interviews are influenced not only by age, but also by gender, ethnicity, shyness, willingness to talk to adults (especially unfamiliar adults), location of interviews, what form the interview takes, and the age, gender, ethnic background and personal style of the researcher. Children also vary in the extent to which they seek to provide accounts that they think adults will want to hear; some may be masters of impression management and adept in steering the interview or choosing what to reveal; they may also recognize the existence and norms governing different types of audience. ${ }^{32}$

Focus groups have been used in research with children with some success, mainly in studies of healthy children. Their use in researching childhood illness has been much more limited, and published work demonstrates some possible problems with the approach - for example, the study of Edwards et al..$^{33}$ comprised a single focus group of four adolescent girls, arguably too small to allow useful conclusions. Although frequently advocated by those working within the new social studies of childhood, focus groups raise important ethical and other challenges in research with families of ill children. Practical issues represent a serious barrier to organizing focus groups, which require people to be in the same place at the same time. For families of a child with cancer, making arrangements of this type may be extremely difficult, and may discourage certain types of families from participating. Other issues arise in relation to known problems in focus groups, including the risk of loss of confidentiality, because focus group participants may not feel bound by the same ethics as the researchers. People may offer confidences in focus groups that they later regret having shared publicly, while others may feel uncomfortable and silenced by dominant characters in the group. Peer expectations may arise in the group and produce apparent consensus while excluding dissonant views. Some participants can become bored or excluded by others, and the perception of the adult as an authority is difficult to manage. ${ }^{14}$ Overall, focus groups require careful handling, especially when they involve sensitive issues such as childhood cancer.

There are perhaps other reasons for caution about qualitative research with children. Fine and Sandstrom ${ }^{32}$ caution that all qualitative research with children will be limited by the 'adultcentric' nature of our understandings, and our tendency to process observations and talk through our own views of the world. The extent to which it can truly serve the emancipatory project claimed for it by sociologists must therefore be open to question.

\section{PSYCHOLOGICAL RESEARCH}

Psychological research in childhood illness investigates two largely discrete domains of functioning: neurocognitive and psychosocial. ${ }^{34}$ As these two domains use very different methods, and an account of both is beyond the scope of this paper, we will focus on research that has investigated the psychosocial functioning of children and their families.

Psychosocial research on childhood cancer examines rates of anxiety, depression, 
poor quality of life and behavioural and social difficulties in children and their families at various stages following the diagnosis and treatment of the disease. Traditionally, psychological research in chronic childhood illness relies on questionnaire-based measurement approaches, and these are subject to the usual difficulties associated with these forms of measurement, coupled with the complexities of selecting developmentally appropriate instruments and conducting research in a family-based context. ${ }^{32,35}$ In a move away from the traditional approach of relying on parents as proxy respondents, there are signs of growing use of multirespondent designs, sometimes involving teachers, classmates and healthcare workers as well as parents and children. ${ }^{36}$ Serious challenges remain, however, in designing instruments that are suitable for direct use with very young or pre-literate children and are that capable of being used in longitudinal studies to examine variations in psychosocial difficulties across different phases of childhood. ${ }^{32}$

Many of the difficulties in conducting research on childhood cancer are by no means unique to psychological research, and the rarity and heterogeneity of the illness mean that it is an extremely challenging field in which to conduct research. To recruit sufficient participants and to examine outcomes for different disease and treatment subgroups, studies need to be conducted at multiple sites. This requirement adds greatly to the expense and complexity of research. It has been argued that research on psychological aspects of childhood illness suffers more from lack of funding than research on physical outcomes of the illness, ${ }^{37}$ and it is plausible that the methodological difficulties found in some studies reflect the politics of research prioritization and scarcity of resources for psychological research, rather than the methodological deficiencies of those conducting research.

Perhaps in an effort to win greater priority for psychological research, the tone of some write-ups of research on the psychological sequelae of childhood cancer makes these seem like quests to find evidence of psychopathology. Much is sometimes made of a few weak correlations, or sub-clinical differences between patients and controls, and there is sometimes a tendency to discount nonsignificant findings as simply methodological caprices. Zebrack and Chesler ${ }^{38}$ have noted how some researchers exhibit an air of disbelief or distrust of findings when these indicate few if any adverse psychological consequences of childhood cancer, and suggest that in some cases this stance goes beyond scientific conservatism.

In contrast to the sociological debate discussed earlier, psychologists rarely attend to political or ideological aspects of their work and the interests that it serves. Researchers in this area might usefully turn their attention to the factors that influence the appraisal of research findings and to wider questions about the consequences and functions of continued surveillance to uncover psychopathology in childhood cancer, when the evidence suggests that such outcomes are far from inevitable and largely restricted to particular subgroups ${ }^{39}$ (although that is certainly not to say that further research on at-risk subgroups is unnecessary). Moreover, we are not aware of any work that has examined children's and families' views about studies on the psychopathology of childhood cancer and their experiences of participating in psychosocial studies. Also worrying is the lack of evidence for many psychosocial interventions that in some areas have become routine and unquestioned aspects of clinical practice. ${ }^{36}$ The potential for ineffective use of resources or even iatrogenic harm resulting from the routine use of such interventions is rarely discussed in the literature, not to mention questions about the acceptability of these interventions to children and their families. Attention to how psychosocial care and services can better support families is therefore a pressing priority. 


\section{BIOLOGICAL AND GENETIC STUDIES}

Biological and genetic studies represent important forms of research in childhood illness, including childhood cancer. Such studies include efforts to identify targets for new cancer treatments, to understand the molecular mechanisms that cause cancer in children, to analyse genetic mutations that might be associated with cancers, and to develop tests that can improve screening and diagnosis of cancers and selection of appropriate treatments (including new pharmacogenetic therapies). Such studies often rely on the availability of suitable material in the form of tumour tissue and matching normal tissue, blood, bone marrow and cerebrospinal fluid for analysis. Recent years have seen the establishment of childhood tumour banks in many countries, including the UK, the USA, Canada, and Australia, to ensure the availability, in sufficient quantities, of appropriately stored samples of tissue from children with cancer.

Among the scientific research community, there is little doubt about the value and importance of tumour banks. ${ }^{40}$ However, research use of human materials, especially those from children, has become the focus of intense public debate, particularly in the UK. Much of the controversy specifically in relation to children has arisen in the context of children's tissues retained after death. An inquiry into practices at the Royal Liverpool Children's Hospital found that whole organs and other materials had been collected and retained without consent or with inadequate consent, resulting in considerable distress, anguish and anger among parents. ${ }^{41}$ The impact of this controversy is evident in the effects on registration of tissue in the United Kingdom Children's Cancer Study Group (UKCCSG) tumour bank. $^{42}$ Separately, particularly in the context of 'genetic' research, there have been growing concerns over issues of privacy, data protection, ownership, and the commercial use of human tissues.
It is clear that research use of tissues from living child donors raises important questions about transactions involving human tissues. These concern the relationships between researchers and researched and the role of intermediaries between them, confidence in the governance of research involving human materials, and the nature of social representations of research involving use of tissues. Some of these arise in the context of the increasing volume and complexity of regulation for the use of human materials. Donations of human materials for research have traditionally been treated as 'gifts' to the scientific community. Advice to the medical and research community from the UK Medical Research Council (MRC) has been that patients should regard their donations as gifts for medical research, and indeed there is explicit reference to the 'gift relationship' in guidance in this area. ${ }^{43}$ This advice emphasizes the benefits of this model in promoting altruistic motivations for participating in research and as a practical way of dealing with legal uncertainties over ownership. Questions are, however, now being raised as to what extent it is possible legally or socially to regard the donation of tissue in all situations as a 'gift', and whether interests in tissues, or the information derived from such material, may persist after donations have been made. ${ }^{44}$ Arguably, people may well retain interests in their tissues after they have donated them, and may wish to control what happens to them, thus challenging the principle that such samples are unfettered 'gifts' or 'abandoned' materials.

Use of the term 'gift' may also imply that the donor foregoes any further claim on the sample, and there are arguments that people may wish to attach conditions to donations, or they may prefer 'specific' consent rather than 'generic' consent - essentially, this 'specific' consent limits the uses to which a sample donated for research can be put. Other issues arise in relation to the level of identification attached to the donated sample, and the extent to which individuals 
have access to information derived from samples - for example, results of DNA analysis conducted on specimens.

Aside from these issues of regulation and research practice, which clearly involve important questions of law and ethics, there is growing social science (and particularly sociological) interest in the separation of body parts from individuals and the use of these materials for the benefit of others, whether directly (e.g. as blood or transplanted organs), or indirectly through research. Some of this can be traced back to the work of Titmuss ${ }^{45}$ whose concept of the 'gift relationship' suggested that blood freely given to meet anonymous needs implies a certain type of social order, in which gifts establish ties of social indebtedness between strangers. However, little is currently known about either staff experiences and views of requesting donations of childhood tissue for childhood cancer tumour banks, or families' experiences of being asked for and making donations.

What is clear, however, is that the notion of a gift relationship regarding exchanges of human tissues has its limitations and is now subject to sustained critique. ${ }^{46}$ These critiques have challenged the adequacy of conceptualizing such exchanges as 'gifts', ${ }^{47}$ and empirical work is beginning to reveal a range of motivations other than altruism for participating in research involving human tissues. ${ }^{48}$ Other research and theory has focused on the increased use of practices that fragment and isolate various bodily components to serve a variety of new technological purposes, ${ }^{49}$ resulting in the re-organization of the boundaries of the body and the recognition of new types of separable, exchangeable and re-incorporable body parts. ${ }^{50}$ The 'commodification' of body parts ${ }^{51}$ has become a prominent theme in this literature, arguing that the severing of parts from bodies and their use in commercial transactions (including research leading to commercial gains) implies that the body is a form of merchandise. A second related theme has concerned the persistence of values of identity and personhood in donated tissues. ${ }^{52}$ In the absence of empirical research, the relevance and explanatory value of this literature (much of it focusing on fragments of body parts transplanted or transferred to other living people) to the area of tissue donations for research is, at present, unclear.

\section{EPIDEMIOLOGICAL RESEARCH IN CHILDHOOD CANCER}

Studies of the incidence and prevalence of childhood cancer may use data from cancer registries. The largest population-based series of childhood cancers in the world is the UK's National Registry of Childhood Tumours, which includes virtually all children diagnosed with cancer in Great Britain since $1962 .{ }^{53}$ Epidemiological research has generally produced reliable estimates of the incidence and prevalence of childhood cancer and different tumour types, but recent years have seen an often bitter controversy about the ethics and legality of populationbased registries that use and make available patient-identifiable data to researchers.

The debate has arisen because in order to ensure the completeness of the data, many cancer registries, including those operating in the UK, have traditionally not explicitly sought consent, effectively therefore running a mandatory system of registration in which all cases are notified. Some have argued that this contravenes patients' rights to confidentiality and data protection. Those responsible for maintaining registries have pointed to the difficulties in obtaining consent for notification at a highly sensitive time $\mathrm{e}^{54}$ and the biases that would result from even a small loss of information. In Germany, a requirement for informed consent to cancer registries led to loss of completeness, while the Nordic countries, by contrast, have operated efficient and complete registration systems without informed consent. In the UK, the situation is still not finally resolved, and further legal developments are awaited. The ethics of public health research, where 
the priorities of individuals (and their doctors) and those of the wider community can be in conflict, are at the centre of these debates. Despite the level of controversy, there is little research investigating children's or families' experiences or views of childhood cancer registries. Issues of particular interest might include the views of survivors of childhood cancer whose parents would have given consent.

Other epidemiological studies, including research into aetiology or long-term outcomes of childhood cancer, use questionnaires or other structured forms of data collection as part of case control studies or cohort studies. Notably, however, children themselves are rarely asked to complete epidemiological questionnaires. Although the ethical and other issues are not necessarily as strikingly evident as those for other forms of clinical research, concern that participating in epidemiological research might risk stimulating painful memories, feelings of guilt, doubt, or recrimination, and the risk of disclosing sensitive information, have been explored in a small number of studies. Jenkinson et $a .^{55}$ investigated these issues among 751 parents of children who had participated in a large case control study investigating the aetiology of childhood cancer, and reported that $19.5 \%$ of case parents and $11.1 \%$ of control parents found recalling pregnancy history 'difficult', and $18 \%$ and $13 \%$ respectively found this area of questioning upsetting. Although $18 \%$ of case parents reported feeling tense and $14 \%$ reported feeling unhappy immediately after the interview, over $90 \%$ of case parents felt glad that they had taken part a few weeks later. Scott et al. ${ }^{56}$ reported similar findings in relation to a questionnaire study of parent/ family member participation in a case control study of Ewing's sarcoma, which had involved structured interviews.

These questionnaire-based studies provide some reassuring evidence that participating in epidemiological research is unlikely to cause significant psychological distress, although they mostly did not use validated instruments. While such research is important and ethically desirable, these studies have looked at a fairly limited range of issues. It is clear that participation in epidemiological research might raise a number of other questions of interest to social science. For example, the extent to which the data given to researchers might be regarded as being as much a 'gift' as human materials, and might be subject to the same concerns about a retention of interest in that gift by donors and to debates about specific and broad consent, has not been explored.

These issues are likely to gain in importance and interest with the growth of genetic epidemiology as a sub-discipline. Genetic epidemiology research represents a shift from the single-gene disorders that have been the traditional focus of genetic research, instead emphasizing the highly complex causal pathways that may be associated with particular diseases. Clearly, the issues discussed earlier concerning the use of human materials and the use of data are all relevant to discussion of people's experiences of genetic epidemiology research in relation to childhood cancer. However, additional distinctive issues arise in this type of research, because of the involvement of family members in the research, and in the context of feedback of individual findings. At present, practice tends to favour nondisclosure of DNA analysis of samples donated for research, in part because the predictive validity and accuracy of such analysis is unknown and likely to be very limited, due to the many uncertainties about the quantification of the contributions of respective environmental and genetic factors to the disease. Other arguments against the provision of feedback include: the potential for conflating the relationship between researcher and patient with that of doctor and patient; the recognition that genetic information should only be provided in genetic counselling sessions; and the potential for harm through revelations of incidental findings such as false paternity.

Further dilemmas arise primarily because of the findings of genetic epidemiology 
research, which can allow the identification of individuals or groups who are at increased risk. Screening programmes based on the findings of genetic research have the potential to result in stigmatization and discrimination against particular groups, and prenatal screening programmes have proved ethically controversial. To date, there is no research on children's or parents' involvement in genetic epidemiology research in childhood cancer, but this is likely to be an important area for future work.

\section{CLINICAL TRIALS IN CHILDHOOD CANCER}

Clinical trials are the mainstay of childhood cancer research, and many of the advances in the last couple of decades in the treatment of childhood cancer have been attributed to this form of research. In the USA, the Children's Cancer Group, founded in 1955 by the National Institutes of Health, became the first cooperative group, and was joined by the Pediatric Oncology Group. ${ }^{57}$ In the UK, the UKCCSG was formed in 1977 and coordinates trials for children with solid tumours, with the MRC supervising leukaemia trials. Similar organizations have been developed in Europe. A fundamental tenet of all of these groups is that clinical trials provide the key to future progress. ${ }^{58}$

Paediatric oncology trials generally define standard treatment as the most effective or least toxic arm of a previous study, and seek to enrol children into a new study in which the experimental arm is hypothesized to be more effective, less toxic, or equally effective. Children and young people show significant survival advantage when treated on trial protocols in specialist centres compared with those who are not. ${ }^{59}$ Most children with cancer are approached for involvement in a trial (over $90 \%$ for children with acute lymphoblastic leukaemia in the UK), although considerable concern has been expressed about lower rates of participation of adolescents and young adults in clinical trials. ${ }^{60}$
A striking feature of clinical trials in childhood cancer has been the absence of a movement towards consumer involvement, such as we have seen in relation to the participation of adults in trials. ${ }^{61,62}$ There has been some research interest in issues of families' understanding and consent to clinical trials in childhood cancer, including in particular their understanding of issues relating to randomization. Crucially, consent for participation in trials must usually be sought very soon after diagnosis, a time of considerable emotional turmoil for families. It is not surprising, therefore, that parents may experience difficulties in understanding key features of trial design, or even in making a distinction between medical treatment and research participation. ${ }^{63}$ Wiley et al. ${ }^{64}$ found that parents who accepted (rather than refused) a clinical trial for their child around the time of diagnosis were more likely to believe (incorrectly) that randomization offers the best opportunity for cure, were less likely to find the thought of randomization frightening, and were more likely to believe (incorrectly) that that randomization would help primarily in the treatment of their child rather than future children. Parents in both the refusing and the accepting groups commented that they made their choices on the basis of their need to trust in their physician. Kodish et al. ${ }^{65}$ observed and taped informed consent conferences for entry to a clinical trial in childhood cancer across six US medical centres and 137 families, and found that half of the parents did not understand randomization. Parents who were less educated, of lower socio-economic status and of minority ethnicity were much less likely to understand randomization; moreover, those who did not understand were more likely to consent to participation. ${ }^{66}$ Other qualitative research has also demonstrated considerable parental confusion about randomization. ${ }^{67}$

\section{CONCLUSIONS}

Research into chronic illnesses of childhood is set to grow substantially. However, in 
contrast to the growing body of important research about adults' experiences of research participation, research in childhood has received much less attention. Many ethical concerns, particularly in clinical research, centre on the conflict between children's protection and participation. The neglect of research on children's perspectives on being research participants has been discussed by a number of writers, who propose that children's exclusion occurs because of researchers' uneasiness about their involvement, and in particular the assumption that children lack the necessary competence and ability to understand research procedures or provide reliable responses. Moreover, as Brannen and $\mathrm{O}^{\prime} \mathrm{Brien}^{68}$ argue, researchers may experience a strong need to defend children from the uncomfortable realities of life, while at the same time discounting the extent to which children's exposure to these may be an unavoidable necessity. Perhaps less obviously, little attention seems to be given to the peculiar ethical position of those (such as parents) asked to participate in research about their child, for whom distinctive ethical questions arise.

Childhood cancer offers an especially fruitful area in which to begin to explore issues relating to research participation, as most children with cancer are approached at some stage in their illness, usually as part of a clinical trial. Children with cancer may also be asked to provide samples for biological and genetic research, and many take part in epidemiological and social science research. Given the high level of participation in research, the absence of research about children's and families' experiences and perspectives in this area is very striking. Research that has directly observed recruitment of children to research, and that has explored issues of relationships, power, language, and role, has been particularly lacking. As a result, questions concerning the involvement of children in research have been debated as ethical or normative principles largely in an empirical vacuum, and debates have often occurred within rather than across disciplinary boundaries. It is important that debates about the involvement of children in research are informed by high-quality social science research about experiences of participants in childhood research, including evidence about the possible risks and benefits from the perspective of participants.

ACKNOWLEDGEMENTS. This paper is based partly on a project funded by the Economic and Social Research Programme's Science and Society Programme, grant number ESRC RES-151-25-0026.

\section{REFERENCES}

1. Santelli J. Human subjects protection and parental permission in adolescent health research. $\underline{\mathcal{f} \text { Adolesc }}$ Health 1997; 21: 384-7.

2. Glantz LH. Research with children. Am f Law Med 1998; 24: 213-44.

3. Royal College of Paediatrics and Child Health. Guidelines for the ethical conduct of medical research involving children. Arch Dis Child 2000; 82: $177-82$.

4. Medical Research Council. Ethics guide: medical research involving children. London: Medical Research Council, 2004.

5. Dixon-Woods M, Young B, Heney D. Rethinking childhood cancer: a multidisciplinary approach to chronic childhood illness. Maidenhead: Open University Press, 2005.

6. Haimes E. What can the social sciences contribute to the study of ethics? Theoretical, empirical and substantive considerations. Bioethics 2002; 16: 89-113.

7. Mayall B. Towards a sociology for childhood: thinking from children's lives. Buckingham: Open University Press, 2002.

8. Glover S. Why won't they listen to us? On giving power and voice to children participating in research. Childhood 2004; 11: 81-93.

9. Alderson P. Children as researchers: the effects of participation rights on research methodology. In: Christensen P, James A, eds. Research into children: perspectives and practices. London: Falmer, 2000: 241-57.

10. Christensen P, Prout A. Working with ethical symmetry in social research with children. Childhood 2002; 9: 477-97. 
11. Field MJ, Behrman RE. Ethical conduct of clinical research involving children. Washington, DC: National Academies Press, 2004.

12. Beardsmore CS. Ethical aspects of respiratory research in infancy and early childhood. Pediatr Pulmonol 1998; 26: 64-8.

13. Morrow V, Richards $M$. The ethics of social research with children: an overview. Children Soc 1996; 10: 90-105.

14. The World Medical Association Policy. Available at: http://www.wma.net/e/policy/b3.htm (accessed August 2006).

15. Goodenough T, Williamson E, Kent E, Ashcroft R. What did you think about that? Researching children's perceptions of participation in a longitudinal genetic epidemiology study. Children Soc 2003; 17: 113-25.

16. British Psychological Society. Ethical principles for conducting research with human participants. Available at: http://www.bps.org.uk/the-society/ethicsrules-charter-code-of-conduct/code-of-conduct/ ethical-principles-for-conducting-research-withhuman-participants.cfm (accessed August 2006).

17. British Sociological Association. Statement of ethical practice for the British Sociological Association. Available at: [http://www.britsoc.co.uk/new_site/user _ doc/Statement $\% 20$ of \%20Ethical \%20Practice. pdf (accessed August 2006).

18. American Sociological Association. Code of ethics and policies and procedures of the ASA Committee on professional ethics. Washington, DC: American Sociological Association, 1999.

19. Greig A, Taylor J. Doing research with children. London: Sage, 1999.

20. James A, Jenks C, Prout A. Theorizing childhood. Cambridge: Polity Press, 1998.

21. Harden J, Scott S, Backett-Milburn K, Jackson S. Can't talk, won't talk? Methodological issues in researching children. Sociol Res Online 2000; 5.

22. Christensen P, James A. Research with children: perspectives and practices. London: RoutledgeFalmer, 2000.

23. Mayall B. Children's childhoods: observed and experienced. London: Falmer Press, 1994.

24. Brannen J, Dodd K, Oakley A, Storey P. Young people, health and family life. Buckingham: Open University Press, 1994.

25. Prout A, James A. Constructing and reconstructing childhood. London: Falmer, 1997.

26. Hatch J. Impression management in kindergarten classrooms: an analysis of children's face to face work in peer interactions. Anthropol Educ Q 1987; 18: $100-15$.

27. Corsaro W. Transitions in early childhood: the promise of comparative, longitudinal ethnography. In: Colby A, Jessor R, Shweder R, eds. Ethnography and human development: context and meaning in social inquiry. Chicago: University of Chicago, 1996: 419-57.
28. Bluebond-Langner M. The private worlds of dying children. Princeton: Princeton University Press, 1978.

29. Shaw I. Unbroken voices: children, young people and qualitative methods. In: Butler I, Shaw I, eds. $A$ case of neglect? Children's experiences and the sociology of childhood. Aldershot: Avebury, 1996: 19-36.

30. Mauthner M. Methodological aspects of collecting data from children: lessons from three research projects. Children Soc 1997; 11: 16-28.

31. Docherty S, Sandelowski M. Interviewing children. Res Nurs Health 1999; 22: 177-85.

32. Fine G, Sandstrom K. Knowing children, participant observation with minors. London: Sage, 1988.

33. Edwards J, Gibson F, Richardson A, Sepion BRE. Fatigue in adolescents with and following a cancer diagnosis: developing and evidence base for practice. Eur f Cancer 2003; 39: 2671-80.

34. Wallander JL, Varni JW. Effects of pediatric chronic physical disorders on child and family adjustment. f Child Psychol Psychiatry 1998; 39: 29-46.

35. Eiser C. Practitioner review: long-term consequences of childhood cancer. 7 Child Psychol Psychiatry 1998; 39: 621-33.

36. Noll RBM, Garstein MA, Vannatta K, Corell J, Bukowski WM, Davies, WH. Social, emotional and behavioural functioning of children with cancer. Pediatrics 1999; 103: 71-8.

37. Bauman LJ, Drotar D, Leventhal JM, Perrin EC, Pless IB. A review of psychosocial interventions for children with chronic health conditions. Pediatrics 1997; 100: 244-51.

38. Zebrack BJ, Chesler MA. Health-related worries, self-image and life outlooks of long-term survivors of childhood cancer. Health Soc Work 2001; 26: 245-56.

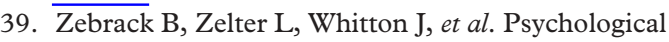
outcomes in long-term survivors of childhood leukaemia, Hodgkin's disease, and non-Hodgkin's lymphoma: a report from the childhood cancer survivor study. Pediatrics 2002; 110: 42-52.

40. Oosterhuis J, Coeburgh J, Van Veen E. Tumour banks: well-guarded treasures in the interest of patients. Nat Rev Cancer 2003; 3: 73-7.

41. Stationery Office. The Royal Liverpool children's inquiry report. London: Stationery Office, 2001.

42. Seale C, Kirk D, Tobin M, et al. Effect of media portrayals of removal of children's tissue on UK tumour bank. BMF 2005; 331: 401-3.

43. Medical Research Council. Human tissue and biological samples for use in research-operational and ethical guidelines. London: MRC, 2001.

44. Human Genetics Commission. Inside information. London: Human Genetics Commission, 2002.

45. Titmuss R. The gift relationship: from human blood to social policy. London: Allen and Unwin, 1970.

46. Tutton R. Person, property and gift: exploring languages of tissue donation to biomedical research. 
In: Tutton R, Corrigan $\mathrm{O}$, eds. Donating and exploiting DNA. London: Routledge, 2004: 19-38.

47. Lock M. The alienation of body tissue and the biopolitics of immortalized cell lines. Body Society 2001; 7: 63-92.

48. Tutton R. Gift relationships in genetics research. Sci Culture 2002; 11: 523-42.

49. Fox M, McHale J. Regulating human body parts and products. Health Care Analysis 2000; 8: 83-6.

50. Rabinow P. French DNA: trouble in purgatory. Chicago: Chicago University Press, 1999.

51. Scheper-Hughes N, Wacquant L. Commodifying bodies. London: Sage, 2002.

52. Waldby C. Biomedicine, tissue transfer and intercorporeality. Feminist Theory 2002; 3: 239-54.

53. Office of National Statistics. Childhood cancer. London: Office of National Statistics, 2004.

54. Illman J. Cancer registries: should informed consent be required? I Natl Cancer Inst 2002; 94: 1269-70.

55. Jenkinson C, Muir K, Hawtin P, Chilvers C. Attitudes and impressions of participants in a study of the causes of childhood cancer. BrF Cancer 2001; 84: 413-16.

56. Scott D, Valery P, Boyle F, Bain C. Does research into sensitive areas do harm? Experiences of research participation after a child's diagnosis with Ewing's sarcoma. Med f Aust 2002; 177: 507-10.

57. Bleyer W. The US Pediatric Cancer Clinical Trials Programmes: the international implications and the way forward. Eur 7 Cancer 1997; 33: 1439-47.

58. Ablett S, Pinkerton C. Recruiting children into cancer trials, role of the United Kingdom Children's Cancer Study Group (UKCCSG). Br f Cancer 2003; 88: 1661-5.
59. McTiernan A. Issues surrounding the participation of adolescents with cancer in clinical trials in the UK. Eur F Cancer Care 2003; 12: 233-9.

60. Barr R. The adolescent with cancer. Eur f Cancer 2001; 37: 1523-7.

61. Tallon D, Chard J, Dieppe P. Relation between agendas of the research community and the research consumer. Lancet 2000; 355: 2037-40.

62. Koops L, Lindley RI. Thrombolysis for acute ischaemic stroke: consumer involvement in design of new randomised controlled trial. BMF 2002; 325: 415.

63. Levi RB, Marsick R, Drotar D, Kodish E. Diagnosis, disclosure, and informed consent: learning from parents of children with cancer. $\mathcal{F}$ Pediatr Haematol Oncol 2000; 22: 3-12.

64. Wiley F, Ruccione K, Moore I, et al. Parents' perceptions of randomization in pediatric clinical trials. Cancer Pract 1999; 7: 248-56.

65. Kodish E, Eder M, Noll R, et al. Communication of randomization in childhood cancer trials. $\mathcal{F} A M A$ 2004; 291: 470-5.

66. Simon C, Zyzanski SJ, Eder M, Raiz P, Kodish ED, Siminoff LA. Groups potentially at risk for making poorly informed decisions about entry into clinical trials for childhood cancer. f Clin Oncol 2003; 21: 2173-8.

67. Kupst M, Patenaude A, Walco G, Sterling C. Clinical trials in pediatric cancer: parental perspectives on informed consent. $\mathcal{F}$ Pediatr Hematol Oncol 2003; 25: 787-90.

68. Brannen J, O’Brien M. Introduction. In: Brannen J, O'Brien M, eds. Children and families: research and policy. London: Falmer Press, 1996. 